\title{
QUALITY EVALUATION OF IMITATION CHICKEN NUGGETS FROM GREY OYSTER MUSHROOM STEMS AND CHICKPEA FLOUR
}

\author{
HUSAIN, H. ${ }^{1,2}$ and HUDA-FAUJAN, N. ${ }^{*}$ \\ ${ }^{1}$ Department of Agrotechnology and Bio-industry, Politeknik Nilai, \\ 71760 Nilai, Negeri Sembilan, Malaysia \\ ${ }^{2}$ Food Biotechnology Programme, Faculty of Science and Technology, \\ Universiti Sains Islam Malaysia, Bandar Baru Nilai, \\ 71800 Nilai, Negeri Sembilan, Malaysia \\ *E-mail:nurhuda@usim.edu.my
}

Accepted 3 September 2020, Published online 25 October 2020

\begin{abstract}
This study was conducted to evaluate the quality of imitation chicken nuggets or ICNs formulated with grey oyster mushroom stems and chickpea flour. Four formulation of ICNs were prepared with the percentage of mushroom stems to chickpea flour were: A (60\%:10\%), B (55\%:15\%), C (50\%:20\%), and D (45\%:25\%). A commercial brand of chicken nugget was chosen as control experiment. All nuggets were analysed for nutritional and cooking properties as well as consumer preference. Results found that protein, fat, and carbohydrate contents of all ICNs were significantly lower $(p<0.05)$ than control chicken nugget. However, the moisture, and crude fibre of all ICNs were significantly higher $(p<0.05)$ than control chicken nugget. Results also showed that ICNs were significantly lower $(p<0.05)$ in cooking loss but were significantly higher $(p<0.05)$ in cooking yield and moisture retention than control chicken nugget. Hedonic test found that consumers did significantly prefer $(p<0.05)$ control chicken nugget compared to all ICNs in attributes chicken aroma, texture, juiciness, taste, and overall acceptance as expected. The ICN B which contained 55\% of grey oyster mushroom stems and 15\% chickpea flour was the most preferred by consumers in term of texture, juiciness, taste, and overall acceptance compared to all ICNs. This findings suggested that grey oyster mushroom stems and chickpea flour have a great potential as alternative ingredients in ICNs formulation.
\end{abstract}

Key words: Imitation chicken nugget; vegetarian nugget; mushroom nugget; chicken nugget preference

\section{INTRODUCTION}

Asian countries contribute the highest percentage of total mushroom (74.64\%) worldwide (Rosmiza et al., 2016). In Malaysia, the total demand for mushroom is projected to be 72,000 tonnes per year (Haimid et al., 2013), and the rate of mushroom consumption is projected to be 2.4 kilograms per person in 2020 (Ministry of Agriculture, and AgroBased Industry Malaysia, 2011). There are seventeen types of mushroom that have been cultivated and marketed in Malaysia including grey oyster, ling zhi, king oyster, black jelly, enoki, white oyster, button, shiitake, paddy straw, abalone, chestnut, red oyster, yellow oyster, fungus, shaggy mane, monkey head, and morning glory (Rosmiza et al., 2016).

* To whom correspondence should be addressed.
Mushrooms have been widely consumed by many people because of their flavour, soft texture, economic, ecological values, and medicinal properties (Sanchez, 2010). The unique flavour and tremendous benefits of nutrients in mushroom have made it as ingredient of gourmet cuisine. Mushrooms are also considered to be a good source of proteins and the fresh mushrooms are also a good source of minerals (Sadler, 2003). Furthermore, mushroom possess umami flavour which are believed to be associated with sulphur containing amino acids and it imparts meaty taste in food product (Phat et al., 2016).

Several studies reported that mushroom could be applied in meat products such as in sausages and patties (Wan Rosli et al., 2011; Arora et al., 2016; Wang et al., 2019). However, the application of mushroom have been focused only on the fruiting 
bodies or cap of mushroom instead of focusing on the stems of the mushroom. The stems were usually omitted and considered as food loss which have created a problem in agro-industrial waste management (Barshteyn \& Krupodorova, 2016).

Imitation meat products are currently primarily aimed and used by vegetarians and semi-vegetarians due to strong emphasis on health and ethical quality aspects (Hoek et al., 2004). Indeed, imitation chicken nuggets (ICNs) that consist of plant-based ingredients (are also known as vegan nuggets) are expected to be the most popular due to commercial chicken nuggets are easily found and available in market than other type of nuggets (Grumbles, 2008). Chickpea flour which contains high protein and starch (20-28\% protein, and $52-57 \%$ carbohydrate) could also be applied in ICNs as an excellent adhesive material in the products (K1lınççeker \& Kurt, 2010).

The tendencies of meat-based food companies in formulating plant-based chicken nugget create demands of having nugget with high nutritional value, pleasant flavour, better taste, and texture as well as low in fats making ICN good choice for consumers. Application of mushroom stems in ICNs have not been explored in detail since it could affect nutritional, cooking and sensorial characteristics of the products. Thus, the aim of this study was to evaluate the nutritional and cooking properties as well as consumer preference of ICNs produced from different percentage of grey oyster mushroom stems in combination with chickpea flour which could be a further potential of vegetarian nuggets.

\section{MATERIALS AND METHODS}

\section{Grey oyster mushroom stems preparation}

Collection of grey oyster mushroom stems were carried out from a mushroom farm (Nas Agro Farm) at Jenderam Hulu, Selangor, Malaysia. The samples were weighed before washing and rinsing using clean tap water. Next, the samples were air-dried using a sieve to drain the excess water until the original weight before washing. Finally, the grey oyster mushroom stems were grounded in small portion for use in ICNs production.

\section{Imitation chicken nugget preparation}

Four formulations of ICNs were prepared as shown in Table 1. Ingredients such as chickpea flour, textured vegetable protein or TVP, corn starch flour, honey, salt, white pepper, chicken stock powder, wheat flour, and bread crumbs were purchased from a supermarket in Nilai, Negeri Sembilan, Malaysia. These formulations were formulated according Huda-Faujan et al. (2006) and Sharima-Abdullah et al. (2018) with modifications.

Prior to analysis, all ingredients were mixed and ground completely for approximately $10 \mathrm{mins}$ and the batter was stored in the refrigerator at $4{ }^{\circ} \mathrm{C}$ before coating process. Ingredients for coating were prepared by mixing $80 \%$ of soy milk (isolated soy protein-based formula) and $20 \%$ wheat flour. Next, the ICNs were shaped into the size of $4.0 \mathrm{~cm} \times 3.0$ $\mathrm{cm} \times 0.5 \mathrm{~cm}$ and coated with the nugget coating before being dipped in breadcrumbs. All ICNs were then packed in a tight container and stored at $-18^{\circ} \mathrm{C}$ before analysis. A commercial brand of nugget that was used as a control in this study contained chicken, corn starch, breadcrumb (contains wheat), vegetable protein (contains soy), spices, salt, chicken seasoning, and monosodium glutamate as stated on the packaging. The price of the chicken nugget was categorised as medium price.

\section{Cooking procedure}

All frozen nuggets were thawed at $4^{\circ} \mathrm{C}$ for an hour before deep-frying in the pan for three minutes in $50 \mathrm{~mL}$ palm oil.

\section{Nutritional composition determination}

Analysis of moisture, ash, protein, fat, carbohydrate, and crude fibre were carried out for all fried nuggets according to the methods of the

Table 1. Formulation of four imitation chicken nuggets or ICNs

\begin{tabular}{lcccc}
\hline Ingredients (\%) & A & B & C & D \\
\hline Grey oyster mushroom stem & 60 & 55 & 50 & 45 \\
Chickpea flour & 10 & 15 & 20 & 25 \\
Textured vegetable protein & 5 & 5 & 5 & 5 \\
Corn starch flour & 6 & 6 & 6 & 6 \\
Water & 15 & 15 & 15 & 15 \\
Honey & 1 & 1 & 1 & 1 \\
Salt & 1 & 1 & 1 & 1 \\
White pepper & 1 & 1 & 1 & 1 \\
Chicken stock powder & 1 & 1 & 1 & 1 \\
\hline
\end{tabular}


Association of Official Analytical Chemists (AOAC, 2005).

\section{Moisture analysis}

Moisture content of all fried nugget samples was determined using mechanical moisture analyser (MX-50, A\&D Company, Limited) which was based on thermogravimetric analysis. The percentage of moisture content was measured by calculating difference of wet weight and dry weight of the sample. Initially, each nugget sample was weighed approximately $2.0 \mathrm{~g}$ and heated at temperature of $200^{\circ} \mathrm{C}$ (for standard drying) to maintain the temperature throughout the whole analysis.

\section{Ash analysis}

Determination of total ash content (presented mineral content) of all fried nugget samples was carried out according to AOAC (2005) Method 920.153 using conventional dry-ashing. Crucibles were pre-dried in oven at $105^{\circ} \mathrm{C}$ overnight and were cooled in a desiccator before adding $3.0 \mathrm{~g}$ of each nugget sample. Next, the samples were then charred on an electric hot plate (Favorit, HS0707V2) until it ceased smoke. After that, the crucibles containing charred samples were placed inside the furnace and temperature was set up to $550^{\circ} \mathrm{C}$. The samples were ignited overnight or until a grey mass (ash) formed, and were then cooled in desiccator. The percentage of total crude ash was calculated using following equation.

$$
\text { Crude ash }(\%) \text { dry basis }=\left[\mathrm{W}_{1} / \mathrm{W}_{2}\right] \times 100
$$

Where $\mathrm{W}_{1}=$ weight of samples after ashing; $\mathrm{W}_{2}=$ weight of samples before ashing.

\section{Protein analysis}

The nitrogen content of all fried nugget samples was analysed using Kjeldahl method (AOAC, 2005) Method 928.08 which include digestion and distillation process. The percentage of crude protein was expressed as total of nitrogen percentage and multiplied by a factor of 6.25 (nitrogen-protein conversion factor for meat and grain sample) as following equation.

Crude protein $(\%)=$ Nitrogen $(\%)$ in samples $\times 6.25$

\section{Fat analysis}

Fat content of all fried nugget samples was automatically carried out using Automatic Soxhlet extraction method (Soxhterm ${ }^{\circledR}$ extractor, Gerhardt). Initially, $9.0 \mathrm{~g}$ of each homogenised nugget sample was weighed, and was then added to the apparatus based on the manual's instruction (Gerhardt's manual). Finally, the residue of extraction was dried in air-drying oven at $105^{\circ} \mathrm{C}$ for overnight, and cooled in desiccator. The fat content of nugget samples was calculated as following equation.

$$
\text { Fat }(\%)=\left[\left(\mathrm{W}_{1}-\mathrm{W}_{2}\right) / \mathrm{W}_{0}\right] \times 100
$$

Where $\mathrm{W}_{0}=$ weight of nugget sample after treatment; $\mathrm{W}_{1}=$ total weight of extraction beaker with boiling stones and extracted fats; and $\mathrm{W}_{2}=$ total weight of extraction beaker and boiling stones.

\section{Carbohydrate analysis}

Content of carbohydrate of all fried nugget samples was determined by totaling up the percentage of moisture, ash, protein, and fat, followed by deducting the result from $100 \%$. The carbohydrate content was determined as available carbohydrate, and was calculated using following equation.

Carbohydrates $(\%)=100-[$ Moisture $(\%)+$ Ash $(\%)$

+ Protein $(\%)+$ Fat $(\%)]$

\section{Crude fibre analysis}

Crude fibre of all fried nugget samples was determined using Gerhardt Method. The crude fibre which is non-soluble that remain after acid and alkali after digestion (minus the content of ash) was calculated using following equation.

$$
\text { Crude fibre }(\%)=[(C-A)-(D-E)] \times 100 / B
$$

Where $\mathrm{A}=$ Weight of FibreBag; $\mathrm{B}=$ Weight of sample (has to be adjusted according to dry content); $\mathrm{C}=$ Weight of crucible and dried FibreBag after digestion; $\mathrm{D}=$ Weight of crucible and ash; $\mathrm{E}=$ Weight of blank of the empty FibreBag $(\mathrm{B}-\mathrm{F})$; $\mathrm{F}=$ Weight of crucible.

\section{Energy content}

Content of energy of all nuggets was determined using Atwater general factor (Atwater \& Woods, 1896) as following equation.

Energy value $(\mathrm{kcal} / \mathrm{g})=[$ Carbohydrate $(\%) \times 4]+$ $[$ Fat $(\%) \times 9]+[$ Protein $(\%) \times 4]$

\section{Cooking loss}

Prior to cooking loss evaluation, all nuggets were weighed and measured before and after frying (Bouton et al., 1978). The nuggets were fried for three minutes using $50 \mathrm{~mL}$ palm oil at temperature $170^{\circ} \mathrm{C}$ and the cooking loss was then measured using following equation.

$$
\text { Cooking loss }(\%)=\left[\left(\mathrm{W}_{\mathrm{a}}-\mathrm{W}_{\mathrm{b}}\right) / \mathrm{W}_{\mathrm{a}}\right] \times 100
$$

Where $\mathrm{W}_{\mathrm{a}}=$ weight of nugget before frying; $\mathrm{W}_{\mathrm{b}}=$ weight of nugget after frying. 


\section{Cooking yield}

All nuggets were weighed and measured before and after frying. Next, the nuggets were fried for three minutes using $50 \mathrm{~mL}$ palm oil at temperature $170^{\circ} \mathrm{C}$ and the cooking yield was then measured using following equation described by Murphy et al. (1975):

$$
\text { Cooking yield }(\%)=\left[\mathrm{W}_{1} / \mathrm{W}_{2}\right] \times 100
$$

Where $\mathrm{W}_{1}=$ weight of nugget after frying; $\mathrm{W}_{2}=$ weight of nugget before frying.

\section{Moisture retention}

The percentage of moisture rentention was measured using following equation (Osman \& Sukru, 2012).

Moisture retention $(\%)=[$ Cooking yield $(\%) \times$ Moisture of fried nugget (\%)] / 100

\section{Hedonic test}

Consumer preference of ICNs was conducted in individual booths at Sensory Laboratory, Universiti Sains Islam Malaysia, Malaysia. The hedonic test was done according to Meilgaard et al. (2007) to evaluate consumers' preference of all ICNs compared to commercial chicken nugget (control nugget). A total of 110 panellists evaluated the nuggets based on hedonic scale of 9-points in attributes of appearance, colour, texture, chicken aroma, taste, and overall acceptance. All nugget samples were cut into rectangle shapes and presented to panellists in a plate with three-random-digit coded number to avoid bias. The 9-point hedonic scale ranging from 1 (extremely dislike) to 9 (extremely like).

\section{Statistical analysis}

All data was analysed using one-way analysis of variance (ANOVA), followed by Tukey HSD Test to compare the means between samples. Data was analysed using IBM SPSS (Statistical Package for the Social Science) software version 21, and the statistical significance was established at $(p<0.05)$. All experiments were replicated twice.

\section{RESULTS AND DISCUSSION}

\section{Nutritional and cooking properties of imitation chicken nuggets}

Nutritional content including moisture, ash, protein, fat, carbohydrate, and crude fibre of fried nuggets are shown in Table 2. Results showed that fried control chicken nugget was significantly higher $(p<0.05)$ in protein, fat, and carbohydrate content than all fried ICNs. However, moisture and fibre content of fried control chicken nugget was significantly lower $(p<0.05)$ than all ICNs.

The moisture content of all fried ICNs ranged from 55.42 to $62.90 \%$ compared to fried control chicken nugget (43.33\%) (Table 2). Moisture content of ICNs in ascending order were ICN C (55.22\%), ICN D (55.42\%), ICN B (57.56\%), and ICN A $(62.90 \%)$. Moisture content of ICNs are higher than control chicken nugget and might be associated with high moisture content of grey oyster mushroom stems compared to mushroom cap. In fact, moisture content of edible mushroom Pleurotus ostreatus (pearl oyster mushroom) stem was $6.30 \%$ higher than in the cap part (3.50\%) of the mushroom (Oluwafemi et al., 2016). Hence, this could explain why the moisture content of all fried ICNs in this

Table 2. Nutritional and cooking properties of four ICNs compared to control chicken nugget

\begin{tabular}{lccccc}
\hline \multirow{2}{*}{ Percentage (\%) } & \multicolumn{5}{c}{ Nugget samples } \\
\cline { 2 - 6 } & Control & $\mathrm{A}$ & $\mathrm{B}$ & $\mathrm{C}$ & $\mathrm{D}$ \\
\hline Moisture & $43.33^{\mathrm{c}}$ & $62.90^{\mathrm{a}}$ & $57.56^{\mathrm{b}}$ & $55.22^{\mathrm{b}}$ & $55.42^{\mathrm{b}}$ \\
Ash & $2.95^{\mathrm{b}}$ & $2.96^{\mathrm{b}}$ & $2.95^{\mathrm{b}}$ & $2.93^{\mathrm{b}}$ & $3.03^{\mathrm{a}}$ \\
Protein & $9.84^{\mathrm{a}}$ & $6.99^{\mathrm{b}}$ & $7.78^{\mathrm{ab}}$ & $8.63^{\mathrm{ab}}$ & $8.74^{\mathrm{ab}}$ \\
Fat & $1.30^{\mathrm{a}}$ & $0.62^{\mathrm{b}}$ & $0.60^{\mathrm{b}}$ & $0.52^{\mathrm{b}}$ & $0.47^{\mathrm{b}}$ \\
Carbohydrate & $42.59^{\mathrm{a}}$ & $26.52^{\mathrm{b}}$ & $31.12^{\mathrm{ab}}$ & $32.71^{\mathrm{ab}}$ & $32.34^{\mathrm{ab}}$ \\
Crude fibre & $4.09^{\mathrm{b}}$ & $4.22^{\mathrm{a}}$ & $4.24^{\mathrm{a}}$ & $5.78^{\mathrm{a}}$ & $6.28^{\mathrm{a}}$ \\
Energy content\# & $221.42^{\mathrm{a}}$ & $139.62^{\mathrm{b}}$ & $161.00^{\mathrm{ab}}$ & $170.04^{\mathrm{ab}}$ & $168.55^{\mathrm{ab}}$ \\
Cooking loss & $0.59^{\mathrm{a}}$ & $-3.18^{\mathrm{b}}$ & $-2.29^{\mathrm{b}}$ & $-2.55^{\mathrm{b}}$ & $-2.79^{\mathrm{b}}$ \\
Cooking yield & $99.42^{\mathrm{b}}$ & $103.18^{\mathrm{a}}$ & $102.29^{\mathrm{a}}$ & $102.55^{\mathrm{a}}$ & $102.79^{\mathrm{a}}$ \\
Moisture retention & $43.07^{\mathrm{b}}$ & $64.89^{\mathrm{a}}$ & $58.88^{\mathrm{a}}$ & $56.62^{\mathrm{a}}$ & $56.97^{\mathrm{a}}$ \\
\hline
\end{tabular}

Notes:

a) Means in the same row with different lowercase letters indicate significant differences $(p<0.05)$ between formulations of ICNs and control chicken nugget

b) Control = commercial chicken nugget; $A=60 \%$ grey oyster mushroom stems and $10 \%$ chickpea flour; $B=55 \%$ grey oyster mushroom stems and $15 \%$ chickpea flour; $C=50 \%$ grey oyster mushroom stems and $20 \%$ chickpea flour; and $D=45 \%$ grey oyster mushroom stems and $25 \%$ chickpea flour.

c) \# Energy content of all fried nuggets were expressed as $\mathrm{kcal} / \mathrm{g}$. 
study was significantly higher $(p<0.05)$ than fried control chicken nugget. The range of moisture content of commercial chicken nuggets in Malaysia was reported from 34.71 to $56.51 \%$ (Lukman et al., 2009).

Ash content of fried ICN D (formulated with $45 \%$ grey oyster mushroom stems and $25 \%$ chickpea flour) was the highest $(3.03 \%)(p<0.05)$ compared to all fried nuggets (Table 2). Ash content of ICN A, ICN B, ICN C, and fried control chicken nugget was found to be similar (2.93 to $2.96 \%)$ to each other $(p>0.05)$. Ash content of chickpea flour was between 3.00 and 3.20\% (Aguilar et al., 2015; Ghribi et al., 2015) while ash content of pearl oyster mushroom stems' (Pleurotus ostreatus) was 5.30\% (Oluwafemi et al., 2016). This could describe why ash content of fried ICN D was found the highest $(p<0.05)$ among all fried nuggets. In fact, ash was determined to measure mineral content of chicken nuggets. In ICNs, mushroom can supply a good proportion of minerals of daily need, where the main constituents of mineral in Pleurotus spp. are potassium and phosphorus (Bano \& Rajarathnam, 1982). Ash content of commercial chicken nuggets in Malaysian market was lower compared to this study, which was between 1.20 and $1.58 \%$ (Lukman et al., 2009).

Protein content of fried control chicken nugget $(9.84 \%)$ was the highest $(p<0.05)$. The ranged of protein content of all fried ICNs was from 6.99 to $8.74 \%$ (Table 2). Increasing amount of grey oyster mushroom stems with decreasing amount of chickpea flour in ICN formulations consistently decreased $(p<0.05)$ protein content of ICNs. According to Ghribi et al. (2015) protein content of chickpea flour was $24.5 \%$ (Kabuli cultivar). Protein content of chickpea flour used in this study was $23.0 \%$ (labelled in the packaging). In addition, protein content of Pleurotus ostreatus stems' was $21.00 \%$ (Oluwafemi et al., 2016) and almost seemed to be similar to protein content of chickpea flour. Therefore, increasing amount of grey oyster mushroom stems with decreasing amount of chickpea flour in ICN formulations does not necessarily decrease protein content of ICNs. Protein content in fried control chicken nugget was most probably contributed by vegetable protein (contains soy) as labelled as the third major ingredient in the packaging. Furthermore, Sharima-Abdullah et al. (2018) reported that protein content of ICNs (formulated with combination of TVP and chickpea flour) was significantly $(p<0.05)$ higher $(10.80$ to $11.78 \%$ ) than commercial control chicken nugget $(9.84 \%)$.

Fat content is one of the important nutrients to claim that the ICNs were healthier than control chicken nugget since ICNs were produced from plant-based sources (did not contain saturated fats and cholesterol). As expected, fried control chicken nugget contained the highest $(p<0.05)$ fat content $(1.30 \%)$, followed by a decline of ICN A $(0.62 \%)$, $\operatorname{ICN} B(0.60 \%), \operatorname{ICN~C~}(0.52 \%)$, and ICN D $(0.47 \%)$ (Table 2). Results found that fat content of fried ICNs consistently decreased $(p<0.05)$ when amount of grey oyster mushroom stems was decreased with increasing amount of chickpea flour. Fat content of chickpea flour used (in this study) was $4.1 \%$ as mentioned on the packaging. In contrary, fat content of mushroom stems of Pleurotus ostreatus was $1.50 \%$ (Oluwafemi et al., 2016). Even though fat content in chickpea flour is generally higher in mushroom stems, however, this finding might be related to amylose content in chickpea flour. Chickpea flour contained amylose ranging from 10.8 to $13.5 \%$ (Chung et al., 2008) but no starch was reported in oyster mushroom (considered no amylose) (Oei, 1996). Thus, when ICNs (from ICN A to ICN D) were fried, the amylose content in chickpea flour increased and absorbed less oil. Oil absorption was negatively correlated with amylose content in starch (Mohamed et al., 1998). This could explain why fat content in fried ICNs decreased when the amount of chickpea flour increased in ICN formulations. Previously, Kilinççeker and Kurt (2010) also reported that addition of chickpea flour in chicken nugget promoted reduction of oil content in fried nugget. Fat content of commercial chicken nuggets in Malaysian market was actually higher that ICNs which ranged from 18.00 to $20.00 \%$ (most probably from chicken fat) (Lukman et al., 2009).

Table 2 shows that fried control chicken nugget contained the highest $(p<0.05)$ carbohydrate content $(42.59 \%)$ compared to all fried ICNs as expected. In general, decreasing amount of grey oyster mushroom stems with increasing amount of chickpea flour in ICN formulations consistently increased $(p<0.05)$ carbohydrate content in ICNs. According to Crisan and Sands (1978) mushrooms stems are high in carbohydrates as glycogen together with pentoses, hexoses, and other polymeric carbohydrates. In fact, carbohydrate content of Pleurotus ostreatus stem was higher $(61.80 \%)$ than its cap $(52.90 \%)$ (Oluwafemi et al., 2016). However, carbohydrate contents of chickpea flour was 70.17\% (Ghribi et al., $2015)$. The highest content $(p<0.05)$ of carbohydrate in fried control chicken nugget was probably due to the content of corn starch and breadcrumb containing wheat as the second and third major ingredient, respectively. Carbohydrate content of commercial chicken nuggets in Malaysian market ranged from 2.49 to $26.05 \%$ (Lukman et al., 2009) which depending on starch types added in nugget formulations.

Fibre content of fried control chicken nugget $(4.09 \%)$ was significantly lower $(p<0.05)$ than all fried ICNs (4.22 to $6.28 \%$ ) (Table 2). Decreasing 
amount of grey oyster mushroom stems with increasing amount of chickpea flour in ICN formulations increased fibre content of ICNs. The fibre content of ICNs in ascending order were ICN A (4.22\%), ICN B (4.24\%), ICN C (5.78\%), and ICN D (6.28\%). Previously, Oluwafemi et al. (2016) reported that fibre content of stalk or stem of edible mushroom Pleurotus ostreatus (pearl oyster mushroom) was $7.50 \%$ lower than in the cap part $(30.10 \%)$ of the mushroom. Moreover, fibre content of chickpea flour (Kabuli cultivar) was $21.8 \%$ (Ghribi et al., 2015). This could explain why the fibre content of all fried ICNs was gradually increased when were formulated with lower amount of grey oyster mushroom stems in combination with higher amount of chickpea flour.

Energy content of fried nuggets ranged from 139.62 to $221.42 \mathrm{kcal} / \mathrm{g}$. As expected, fried control chicken nugget was significantly higher $(p<0.05)$ in energy content than all fried ICNs. Energy content of fried control chicken nugget was mainly contributed by fat content. It was observed that decreasing amount of grey oyster mushroom stem with increasing amount of chickpea flour generally increased energy content of ICNs and was line with chickpea content in the ICNs. In a recent study, El-Anany et al. (2020) reported that energy content of fried chicken nuggets ranged from 182.86 to $282.78 \mathrm{kcal} / \mathrm{g}$. The energy content of fried control chicken nugget was the highest $(p<0.05)$ compared to chicken nuggets formulated with frozen white cauliflower. A decreament content of chicken skin from 20 to $0 \%$ and replacing with frozen-blanched cauliflower significantly $(p<0.05)$ decreased energy content of fried chicken nuggets.

The cooking properties of chicken nuggets are also shown in Table 2. Results found that fried control chicken nugget significantly $(p<0.05)$ showed the highest percentage of cooking loss $(0.59 \%)$ as expected due to the highest fat content in the product. Decreasing amount of grey oyster mushroom stems with increasing chickpea flour in ICN formulations increased cooking loss ranged from -2.79 to $-3.18 \%$ (from ICN D to ICN A). According to Verma et al. (2012) higher amount of fat in a meat product causes higher moisture loss during frying and might be associated with the loss of emulsion stability of hydrophobic interaction between fats and moisture in the product. Furthermore, fat content of mushroom stems of Pleurotus ostreatus (1.50\%) was lower (Oluwafemi et al., 2016) compared to chickpea flour (7.98\%) (Xiao et al., 2015). This could explain why cooking loss in control chicken nugget was the highest compared to all ICNs formulation, and decreasing amount of grey oyster mushroom stems with increasing chickpea flour in ICN formulations increased cooking loss. Cooking loss is one of the crucial characteristics that affect juiciness of meatbased product (Sharima-Abdullah et al., 2018).

In the assessment of cooking yield, it was found that all fried ICNs were significantly $(p<0.05)$ higher in cooking yield than fried control chicken nugget $(99.42 \%)$ (Table 2$)$. The cooking yield of ICNs seemed to be similar to each other $(p>0.05)$ which ranged from 102.29 to $103.18 \%$. Addition of dietary fibre increased cooking yield and might be related to their high ability to retain moisture and fat in food matrix (Aleson-Carbonella et al., 2005). Furthermore, Santhi and Kalaikannan (2014) reported that nuggets incorporated with oat flour significantly increased $(p<0.05)$ cooking yield (99.46 to $99.85 \%)$ compared to chicken nugget without oat (control sample) (96.46\%). The fibre content of all fried ICNs was found higher than fried control chicken in the present study. Hence, this could explain why cooking yield of all fried ICNs was higher than fried control chicken nugget.

Moisture retention of all fried ICNs (56.97 to $64.89 \%)$ was also found significantly $(p<0.05)$ higher than fried control chicken nugget (43.07\%) (Table 2). However, decreasing amount of grey oyster mushroom stems with increasing amount of chickpea flour in ICN formulations obtained a gradual reduction of moisture retention. The characteristic of retaining moisture in mushroom is a beneficial property including flavour concentrate in foods, improving texture, and mouthfeel (Oei, 2003). Addition of mushroom stems and legume (i.e. chickpea flour) enhance moisture retention (Jayasinghe et al., 2013) and might be due to high content of polysaccharides in grey oyster mushroom stems (Oluwafemi et al., 2016) which are able to form tridimensional matrix within the nugget.

\section{Consumer preference of nuggets}

Table 3 presents the hedonic test data of nuggets' preference by 110 panellists. Results showed that consumers' preference of sensory attributes include chicken aroma, texture, juiciness, taste, and overall acceptance were significantly higher $(p<0.05)$ in control chicken nugget than all ICNs demonstrated that consumers preferred the commercial chicken nugget in market. The mean score of appearance of control chicken nugget was also the highest but did not significantly differed $(p>0.05)$ compared to all ICNs. The mean score of attributes appearance, chicken aroma, texture, juiciness, taste, and overall acceptance of control chicken nugget were $6.50,7.26,6.56,6.33,6.94$ and 6.69 , respectively.

In the assessment of nuggets' appearance, results found that preference of panellists among ICNs was similar $(p>0.05)$ to control chicken nugget (6.50) where the mean score of ICNs ranged from 6.22 to 6.31. Previously, Sharima-Abdullah et al. (2018) 
Table 3. Mean scores of hedonic test of four ICNs compared to control chicken nugget

\begin{tabular}{lccccc}
\hline \multirow{2}{*}{ Attributes } & \multicolumn{5}{c}{ Nugget samples } \\
\cline { 2 - 6 } & Control & $\mathrm{A}$ & $\mathrm{B}$ & $\mathrm{C}$ & $\mathrm{D}$ \\
\hline Appearance & $6.50^{\mathrm{a}}$ & $6.30^{\mathrm{a}}$ & $6.31^{\mathrm{a}}$ & $6.22^{\mathrm{a}}$ & $6.31^{\mathrm{a}}$ \\
Chicken aroma & $7.26^{\mathrm{a}}$ & $4.83^{\mathrm{b}}$ & $4.85^{\mathrm{b}}$ & $4.68^{\mathrm{b}}$ & $4.98^{\mathrm{b}}$ \\
Texture & $6.56^{\mathrm{a}}$ & $4.36^{\mathrm{b}}$ & $4.57^{\mathrm{b}}$ & $4.43^{\mathrm{b}}$ & $4.51^{\mathrm{b}}$ \\
Juiciness & $6.33^{\mathrm{a}}$ & $4.07^{\mathrm{b}}$ & $4.17^{\mathrm{b}}$ & $4.09^{\mathrm{b}}$ & $4.06^{\mathrm{b}}$ \\
Taste & $6.95^{\mathrm{a}}$ & $3.72^{\mathrm{b}}$ & $3.84^{\mathrm{b}}$ & $3.61^{\mathrm{b}}$ & $3.78^{\mathrm{b}}$ \\
Overall acceptance & $6.99^{\mathrm{a}}$ & $4.04^{\mathrm{b}}$ & $4.19^{\mathrm{b}}$ & $3.91^{\mathrm{b}}$ & $4.05^{\mathrm{b}}$ \\
\hline
\end{tabular}

Notes:

a) Means in the row with different lowercase letters indicate significant differences $(p<0.05)$ between formulations of ICNs and control chicken nugget.

b) Control = commercial chicken nugget;

$A=60 \%$ grey oyster mushroom stems and $10 \%$ chickpea flour;

$B=55 \%$ grey oyster mushroom stems and $15 \%$ chickpea flour;

C $=50 \%$ grey oyster mushroom stems and $20 \%$ chickpea flour; and

$\mathrm{D}=45 \%$ grey oyster mushroom stems and $25 \%$ chickpea flour.

reported that mean score of appearance of ICNs produced from chickpea flour in combination with TVP ranged from 5.44 to 5.98. Addition of chickpea flour in a food product provides better appearance and colour since chickpea flour contribute to the pleasant yellow colour (Padalino et al., 2014). In hamburger, addition of chickpea and lentil flour also increased $(p>0.05)$ the mean score of appearance (Motamedi et al., 2015).

The mean scores of 7.26 for chicken aroma was given by consumers in control chicken nugget. However, the range of mean scores of chicken aroma of ICNs was lower $(p<0.05)$ which between 4.68 and 4.83. Results found that the mean score among ICNs did not significantly differ $(p>0.05)$ among the ICNs. Previously, Sharima-Abdullah et al. (2018) reported that the range of mean scores of chicken aroma of ICNs produced from chickpea flour and TVP was between 4.91 and $5.25(p>0.05)$ and was also lower than control chicken nugget's mean score (7.80).

In term of ICNs texture, it was found that panellists' mean score were between 4.36 and 4.57 ( $p>0.05$ ) compared to control chicken nugget (6.56). However, Sharima-Abdullah et al. (2018) obtained that the mean score of texture of ICNs produced from chickpea flour and TVP ranging between 4.75 and 5.04. Decreasing amount of TVP with the increasing amount of chickpea flour generally decreased panellists' preference and might be related to the decrease of TVP which was able to provide fibrous structure in the nugget similar to the meat texture.

Meat juiciness is actually defined as amount of moisture released in the mouth when chewing the meat product. In this study, the mean score of ICNs' juiciness are similar $(p>0.05)$ which ranged from 4.07 to 4.17 and was significantly $(p<0.05)$ lower compared to control chicken nugget (6.33). Previously, Wan Rosli and Solihah (2012) reported that the mean score of beef patties' juiciness formulated with and without combination grey oyster mushroom are similar $(p>0.05)$ for which the panellists' mean score was between 4.15 and 4.62. However, the mean score of juiciness of Malaysian commercial chicken nugget was found between 4.40 and 5.64 and might be due to different types of ingredients (starch, soy protein, and fat) in the products (Lukman et al., 2009).

In the context of taste attribute, it was found that panellists' mean score of ICNs ranged between 3.61 to $3.84(p>0.05)$ and were lower in ICNs produced from chickpea flour and TVP (4.75 to 5.04) (Sharima-Abdullah et al., 2018). However, the mean score of taste of Malaysian commercial chicken nugget was found between 4.12 and 5.60 (Lukman et al., 2009). Moreover, the mean score of overall acceptance of ICNs in this study ranged between 3.91 and $4.19(p>0.05)$ and were also lower in ICNs produced from chickpea flour and TVP (5.03 to 5.21) (Sharima-Abdullah et al., 2018). Previously, Wan Rosli and Solihah (2012) reported that the mean score of beef pattie's overall acceptance formulated with and without combination grey oyster mushroom ranged from 4.08 to $4.80(p>0.05)$ and was found lower than panellists' mean score of overall acceptance of Malaysian commercial chicken nugget (4.56 to 5.84) (Lukman et al., 2009). This might be associated to the TVP as this ingredient is always applied in commercial chicken nugget and provide familiar taste to consumer compared to mushroom in chicken nugget.

\section{CONCLUSION}

Production of ICNs from grey oyster mushroom stems and chickpea flour significantly $(p>0.05)$ changed nutritional and cooking properties of fried 
chicken nuggets except in ash content. As expected, consumer preferred commercial control chicken nugget compared to all ICNs. However, among all ICNs it was found that ICN B (55\% of grey oyster mushroom stems and $15 \%$ chickpea flour) was the most preferred by consumers in term of texture, juiciness, taste, and overall acceptance. These findings concluded that ICNs from mushroom stems and chickpea flour have a potential to be an alternative of chicken-based nugget in commercial market.

\section{ACKNOWLEDGEMENTS}

The authors acknowledge the financial support provided by Ministry of Education, Malaysia for the scholarship funding. Appreciation is also expressed to Mr Nabil Sanusi from Nas Agro Farm, Jenderam Hulu, Sepang, Selangor, Malaysia to provide grey oyster mushroom stems for this study. Furthermore, we also thank Universiti Sains Islam Malaysia for providing the laboratory facilities for conducting this study. Special appreciation to Mrs. Rina Abdul Wahap, Mrs. Norhafiza Abdul Ghafar, and Mrs. Normah Haron for their assistance.

\section{REFERENCES}

Aguilar, N., Albanell, E., Minarro, B. \& Capellas, M. 2015. Chickpea and tiger nut flours as alternatives to emulsifier and shortening in gluten-free bread. LWT - Food Science and Technology, 62: 225-232.

Aleson-Carbonella, L., Fernández-López, J., PérezAlvarez, J.A. \& Kuri, V. 2005. Characteristics of beef burger as influenced by various types of lemon albedo. Innovative Food Science and Emerging Technologies, 6(2): 247-255.

AOAC (Association of Official Analytical Chemists). 2005. Official Methods of Analysis. 18th Ed. Washington D.C., Washington.

Arora, B., Kamal, S. \& Sharma, V.P. 2016. Effect of binding agents on quality characteristics of mushroom based sausage analogue. Journal of Food Processing and Preservation, 41(5): e13134.

Atwater, W.O. \& Woods, C.D. 1896. The Chemical Composition of American Food Materials. US Official Experiment Stations, Experiment Station Bulletin No. 28. Washington, D.C., Washington.

Bano, Z. \& Rajarathnam, S. 1982. Pleurotus Mushrooms as a Nutritious Food. Chinese University Press, Hongkong.
Barshteyn, V. \& Krupodorova, T. 2016. Utilization of agro-industrial waste by higher mushrooms: modern view and trends. Journal of Microbiology, Biotechnology and Food Sciences, 5(6): 563-577.

Bouton, P.E., Harris, P.E., Shorthose, W.R. \& Ellis, R.W. 1978. Comparison of some properties of meat from normal steers and steers heterozygous for muscular hypertrophy. Journal of Meat Science, 2: 161-167.

Chung, H.J., Liu, Q., Hoover, R., Warkentin, T.D. \& Vandenberg, B. 2008. In vitro starch digestibility, expected glycemic index, and thermal and pasting properties of flours from pea, lentil and chickpea cultivars. Food Chemistry, 111(2): 316-321.

Crisan, E.V. \& Sands, S.A. 1978. Nutritional Value of Edible Mushrooms in the Biology and Cultivation of Edible Mushrooms. New York Academic Press, New York.

El-Anany, A.M., Ali, R.F. \& Elanany, A.M. 2020. Nutritional and quality characteristics of chicken nuggets incorporated with different levels of frozen white cauliflower. Italian Journal of Food Science, 32(1): 45-59.

Ghribi, A.M., Maklouf, I., Blecker, C., Attia, H. \& Besbes, S. 2015. Nutritional and compositional study of Dei and Kabuli chickpea (Cicer arietinum L.), flours from Tunisian cultivars. Advanced of Food Technology Nutritional Science Open Journal, 1(2): 38-47.

Grumbles, S.L. 2008. Optimization of ingredient and process parameters for chicken nuggets. MSc Thesis. Oklahoma State University, California.

Haimid, M.T., Rahim, H. \& Dardak, R.A. 2013. Understanding the mushroom industry and its marketing strategies for fresh produce in Malaysia. Economic and Technology Management Review, 8: 27-37.

Hoek, A.C., Luning, P.A., Stafleu, A. \& deGraaf, C. 2004. Food-related lifestyle and health attitudes of Dutch vegetarians, non-vegetarians consumers of meat substitutes and meat consumers. Appetite, 42: 265-272.

Huda-Faujan N., Noriham, A., Norrakiah, A.S. \& Babji, A.S. 2006. Antioxidant effects of Cosmos caudatus, Polygonum minus and Murraya koenigii in spent hen burger. Malaysian Journal of Animal Science, 1: 72-77.

Jayasinghe, C.V.L., Silva, S.S.G. \& Jayasinghe, J.M.J.K. 2013. Quality improvement of tilapia fish nuggets by addition of legume flour as extenders. Journal of Food and Agriculture, 6(12): $32-44$. 
Kılınççeker, O. \& Kurt, Ş. 2010. Effects of chickpea (Cicer arietinum) flour on quality of deep-fat fried chicken nugget. Journal of Food, Agriculture and Environment, 8(2): 47-50.

Lukman, I., Huda, N. \& Ismail, N. 2009. Physicochemical and sensory properties of commercial chicken nuggets. Asian Journal of Food and Agro-Industry, 2(02): 171-180.

Meilgaard, M., Civille, G.V. \& Carr, B.T. 2007. Sensory Evaluation Techniques. 4th Ed. Taylor and Francis, London.

Ministry of Agriculture and Agro-Based Industry Malaysia. 2011. Bab 7: Memacu Pertumbuhan Pertanian Bernilai Tinggi. In Dasar Agromakanan Negara (2011-2020) (DAN), Percetakan Watan Sdn. Bhd., Kuala Lumpur.

Mohamed, S., Abd Hamid, N. \& Abd Hamid, M. 1998. Food components affecting the oil absorption and crispness of fried batter. Journal of the Science of Food and Agriculture, 78(1): 39-45.

Motamedi, A., Vahdani, M., Baghaei, H. \& Borghei, M.A. 2015. Considering the physicochemical and sensorial properties of Momtaze Hamburgers containing lentil and chickpea seed flour. Nutrition and Food Sciences Research, 2(3): 55-62.

Murphy, E.W., Criner, P.E. \& Gray, B.C. 1975. Comparisons of methods for calculating retention of nutrients in cooked foods. Journal of Agricultural and Food Chemistry, 23(6): 1153-1157.

Oei, P. 1996. Mushroom Cultivation with Special Emphasis on an Appropriate Techniques for Developing Countries. Backhuys Publishers, The Netherlands.

Oei, P. 2003. Mushroom Cultivation with Appropriate Technology for Mushroom Growers. Backhuys Publication, The Netherland.

Oluwafemi, G.I., Seidu, K.T. \& Fagbemi, T.N. 2016. Chemical composition, functional properties and protein fractionation of edible oyster mushroom (Pleurotus ostreatus). Annals. Food Science and Technology, 179(1): 218-223.

Osman, K. \& Şukru, K. 2012. The effects of cereal and legume flour on the quality characteristics of beef patties. Kafkas Universitesi Veteriner Fakultesi Dergisi, 18(5): 725-730.

Padalino, L., Mastromatteo, M., Lecce, L. Spinelli, S., Contò, F. \& Nobile, M.A.D. 2014. Chemical composition, sensory and cooking quality evaluation of durum wheat spaghetti enriched with pea flour. International Journal of Food Science and Technology, 49(6): 1544-1556.
Phat, C., Moon, B. \& Lee, C. 2016. Evaluation of umami taste in mushroom extracts by chemical analysis, sensory evaluation, and an electronic tongue system. Food Chemistry, 192: 10681077.

Rosmiza, M.Z., Davies, W.P., Rosniza-Aznie, C.R., Jabil, M.J. \& Mazdi, M. 2016. Prospects for increasing commercial mushroom production in Malaysia: challenges and opportunities. Mediterranean Journal of Science Social, 7: 406-415.

Sadler, M.J. 2004. Meat alternatives - market developments and health benefits. Trends in Food Science and Technology, 15(5): 250-260.

Sanchez, C. 2010. Cultivation of Pleurotus ostreatus and other edible mushrooms. Applied Microbiology and Biotechnology, 85(5): 13211337.

Santhi, D. \& Kalaikannan, A. 2014. The effect of the addition of oat flour in low-fat chicken nuggets. Journal of Nutrition \& Food Sciences, 4(1): 260.

Sharima-Abdullah, N., Hassan, C.Z., Arifin, N. \& Huda-Faujan, N. 2018. Physicochemical properties and consumer preference of imitation chicken nuggets produced from chickpea flour and textured vegetable protein. International Food Research Journal, 25(3): 1016-1025.

Verma, A.K., Banarjee, R. \& Sharma, B.D. 2012. Quality of low fat chicken nuggets: effect of sodium chloride replacement and added chickpea (Cicer arietinum L.) hull flour. AsianAustralasian Journal of Animal Science, 25(2): 291-298.

Wan Rosli, W.I. \& Solihah, M.A. 2012. Effect on the addition of Pleurotus sajor-caju (PSC) on physical and sensorial properties of beef patty. International Food Research Journal, 19(3): 993-999.

Wan Rosli, W.I., Solihah, M.A., Aishah, M., Nik Fakurudin, N.A. \& Mohsin, S.S.J. 2011. Colour, textural properties, cooking characteristics and fibre content of chicken patty added with oyster mushroom (Pleurotus sajor-caju). International Food Research Journal, 18(2): 621-627.

Wang, L., Guo, H., Liu, X., Jiang, G., Li, C., Li, X. \& Li, Y. 2019. Roles of Lentinula edodes as the pork lean meat replacer in production of the sausage. Meat Science, 156: 44-51.

Xiao, Y., Xing, G., Rui, X., Li, W., Chen, X., Jiang, M. \& Dong, M. 2015. Effect of solid-state fermentation with Cordyceps militaris SN-18 on physicochemical and functional properties of chickpea (Cicer arietinum L.) flour. LWT - Food Science and Technology, 63(2): 1317-1324. 
